\title{
Evaluasi Pemisahan Alkilbenzena Menggunakan Kolom Monolith Berbasis Polimer Organik secara Kromatografi Cair Kinerja Tinggi
}

\author{
Septi Fajar Raenia ${ }^{a}$, Unsania Haresmawati ${ }^{\mathrm{b}}$, Ani Mulyasuryani ${ }^{\mathrm{a}}$, and Akhmad \\ Sabarudin $^{\text {a,b* }}$ \\ ${ }^{a}$ Jurusan Kimia, FMIPA,Universitas Brawijaya, Jl. Veteran Malang 65145, Indonesia \\ ${ }^{b}$ Pusat Penelitian Advance System and Material Technology (ASMAT), Jl. Veteran Malang 65145, Indonesia, \\ Telp/Fax: +62-341-575838/+62-341-554403
}

* Corresponding author

E-mail: sabarjpn@ub.ac.id atau sabarjpn@gmail.com

DOI : 10.20961/alchemy.14.1.11266.37-50

Received 18 May 2017, Accepted 10 October 2017, Published online 1 March 2018

\begin{abstract}
ABSTRAK
Kolom monolith berbasis polimer organik poli-(lauril metakrilat-co-etilen dimetakrilat) disintesis secara in situ kopolimerisasi dalam kolom silicosteel dengan ukuran panjang $10 \mathrm{~cm}$ dan diameter dalam 1,02 $\mathrm{mm}$. Kolom monolith ini digunakan untuk pemisahan alkilbenzena secara Kromatografi Cair Kinerja Tinggi (KCKT) fasa terbalik. Pada penelitian ini, efisiensi pemisahan ditingkatkan dengan menggunakan kolom monolith poli-(LMA-co-EDMA) untuk memisahkan senyawa alkilbenzena melalui tiga parameter, yakni temperatur kolom, pemisahan secara isokratik dan pemisahan secara gradien. Temperatur kolom yang digunakan berkisar antara $27-50^{\circ} \mathrm{C}$. Hasil yang diperoleh menunjukkan bahwa temperatur optimum untuk pemisahan alkilbenzena secara isokratik yaitu $27^{\circ} \mathrm{C}$ yang setara dengan temperatur ruang dengan fasa gerak asetonitril-air (50:50 w/w). Pemisahan alkilbenzena yang lebih efisien ditunjukkan dari penggunaan mode gradien ditandai dengan nilai peak capacity, faktor retensi dan jumlah plat teoritis yang lebih baik. Fasa gerak yang digunakan pada pemisahan secara gradien yaitu pelarut A yang terdiri atas asetonitril-air $(40: 60 \mathrm{w} / \mathrm{w})$ dan pelarut B yang terdiri atas asetonitril-air (60:40 w/w) dengan waktu gradien 20-40 menit 0-100\% B. Perubahan waktu gradien berpengaruh terhadap faktor retensi dan peak capacity.
\end{abstract}

Kata Kunci : alkilbenzena, efisiensi, gradien, KCKT, monolith.

\section{ABSTRACT}

Evaluation of Organic Polymer-Based Monolithic Column by High Performance Liquid Chromatography for The Separation of Alkyl Benzenes. Organic polymer-based monolithic column of poly(lauryl methacrylate-co-ethylene dimethacrylate) has been prepared by in- situ copolymerization inside of silicosteel column with the size of $100 \mathrm{~mm}$ long x $1.02 \mathrm{~mm}$ i.d. This kind of monolith column used for separation of alkylbenzenes using reversed-phase high performance liquid chromatography (HPLC). The efficiency separation on this research is improved by using poly-(LMA-co-EDMA) monolithic column for separation of alkyl benzene compounds using three strategies involving optimization column temperature, isocratic elution mode, and gradient elution mode. The applied column temperatures were varied in the range of $27-50{ }^{\circ} \mathrm{C}$. It was found that room temperature in isocratic mode with the mobile phase of acetonitrilewater $(50: 50 \mathrm{w} / \mathrm{w})$ showed the excellent efficiency indicated by baseline-resolved of each peak of alkyl benzenes. The resulted separation efficiency by employing gradient elution mode exceeded its counterpart (isocratic mode), which is indicated by better in peak capacity, retention factor, and number theoritical plate. Two different mobile phases for gradient elution mode, composed of A that contain of acetonitrile-water 
$(40 / 60 \mathrm{w} / \mathrm{w})$ and $B$ that contain of acetonitrile-water $(60 / 40 \mathrm{w} / \mathrm{w})$ were utilized in the range of $20-40 \mathrm{~min}$ for $0-100 \%$ B. It was found that increasing gradient time strongly affect to the retention factor and peak capacity.

Keywords: alkylbenzenes, efficiency, gradient, HPLC, monolithic column.

\section{PENDAHULUAN}

Kromatografi cair kinerja tinggi (KCKT) telah dikenal sebagai suatu metode pemisahan yang diaplikasikan pada berbagai jenis pemisahan. Pemisahan dengan KCKT terjadi pada kolom yang berisi fasa diam yang dialiri oleh fasa gerak. Kolom monolith banyak menarik perhatian dalam dunia pemisahan secara kromatografi (Moyna, 2012). Monolith didefinisikan sebagai single rod kontinyu material berpori. Berdasarkan material yang digunakan, monolith dikelompokkan menjadi tiga macam, antara lain monolith silika, polimer organik dan hibrid (Krenkova and Svec, 2009; Nema et al., 2014). Keunggulan dari kolom monolith yakni memiliki karakteristik porositas yang tinggi, sehingga dapat digunakan pada pemisahan pada laju alir tinggi dengan tekanan balik rendah. Aliran konvektif fasa gerak dan sampel dalam kolom monolith menyebabkan berkurangnya pengaruh Difusi Eddy sehingga dapat meningkatkan efisiensi pemisahan. Hal ini berbeda dengan aliran random dalam penggunaan kolom konvensional. Penggunaan KCKT menghasilkan pemisahan yang lebih cepat dengan efisiensi yang lebih baik dibandingkan dengan kromatografi berbasis gravitasi (Hao et al., 2008; Sabarudin et al., 2012; Tasfiyati et al., 2016; Unger et al., 2013).

Efisiensi kromatografi dapat dijelaskan oleh teori persamaan Van Deemter dimana interaksi analit dengan fasa diam dan fasa gerak, laju alir serta diameter partikel pengisi kolom mempengaruhi efisiensi kromatografi (Gritti and Guiochon, 2013). Berdasarkan persamaan tersebut, semakin kecil dimensi partikel pengisi kolom, efisiensi dan resolusi pemisahan semakin meningkat (Mangelings and Heyden, 2010). Hal tersebut mendorong pengembangan kolom partikel dengan diameter kolom yang lebih kecil dan berpori. Partikel berpori diyakini mampu mengurangi jarak tempuh dan meningkatkan kecepatan pemisahan seiring terjadinya peningkatan kinetika transfer massa. Pengaruh lain yang dapat terjadi dari partikel berpori adalah difusi longitudinal dan pelebaran puncak kromatogram yang mengarah pada penurunan efisiensi pemisahan (Unger et al., 2013). Permasalahan tersebut diatasi dengan pengembangan material monolit sebagai fasa diam berbasis partikel. 
Shu et al. (2011) mengembangkan kolom monolith berbasis polimer organik metakrilat C12 pada KCKT fasa terbalik. Monolith tersebut dibuat menggunakan lauril metakrilat sebagai monomer fungsional dan etilen dimetakrilat sebagai cross-linker, sehingga terbentuklah poli-(laurilmetakrilat-co-etilendimetakrilat) atau yang dikenal dengan poli-(LMA-co-EDMA). Pada penelitian ini kolom tersebut berukuran panjang 10 $\mathrm{cm}$ dan diameter dalam 1,02 $\mathrm{mm}$ dan digunakan untuk memisahkan sampel alkilbenzena yang terdiri dari campuran urasil, toluen, etilbenzena, propilbenzena, butilbenzena dan amilbenzena dengan menggunakan fasa gerak asetonitril-air $(50: 50 \mathrm{v} / \mathrm{v})$. Sampel alkilbenzena digunakan untuk mengetahui efisiensi kinerja dari kolom poli-(LMA-coEDMA) dalam memisahkan sampel yang memiliki deret homolog yang sama dengan penambahan satu metil pada masing-masing strukturnya. Struktur dari senyawa benzena dan alkilbenzena ditujukkan pada Gambar 1. Pemisahan dilakukan pada temperatur ruang dengan laju alir $0,05 \mathrm{~mL} /$ menit. Hasil pemisahan menunjukkan bahwa kolom monolith poli-(LMA-co-EDMA) mampu menghasilkan lebih dari 5000 plat teoritis dan faktor retensi 3-4 dengan tekanan balik kurang dari $1 \mathrm{MPa}$. Hal ini memperlihatkan bahwa penggunaan kolom monolith berbasis polimer organik poli-(LMA-co-EDMA) mampu memberikan efisiensi pemisahan yang baik untuk pemisahan senyawa alkilbenzena (Shu et al., 2011).

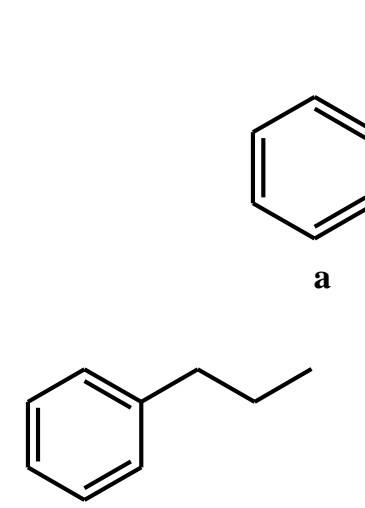

d<smiles>Cc1ccccc1</smiles>

b<smiles>CCc1ccccc1</smiles>

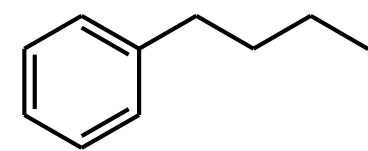

e

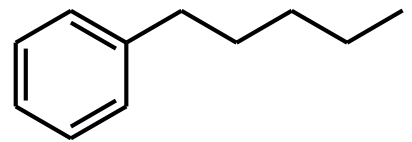

f

Gambar 1. Struktur dari benzena (a), toluena (b), etilbenzena (c), propilbenzena (d), butilbenzena (e), amilbenzena (f)

Salah satu parameter utama dalam pemisahan secara kromatografi adalah temperatur. Temperatur kolom secara signifikan berpengarih terhadap viskositas fasa gerak, difusi analit dan transfer massa analit antara fasa diam dan fasa gerak. Secara kinetika, temperatur kolom dapat memperbaiki kinerja KCKT dalam pemisahan analit. Pemisahan dapat berlangsung lebih cepat tanpa mengurangi efisiensi dengan peningkatan temperatur (Hao et al., 2008). Dalam KCKT fasa terbalik, penggunaan temperatur kolom 
telah banyak dilakukan. Temperatur berpengaruh pada faktor retensi dan selektivitas. Sebelum tahun 1970, Giddings (1965) telah mempelajari fungsi temperatur dalam pemisahan. Giddings menyimpulkan bahwa temperatur memiliki pengaruh pada plat teoritis. Peningkatan temperatur akan mengurangi koefisien difusi sehingga meningkatkan jumlah plat teoritis. Selain itu, Synder juga mempelajari bahwa dalam KCKT fasa terbalik, temperatur memiliki pengaruh pada faktor retensi dan dapat mengurangi waktu analisis, namun juga dapat menurunkan resolusi (Dolan, 2002; Synder and Kirkland, 1979).

Parameter penting lainnya selain temperatur, yang tak kalah penting adalah fasa gerak. Dalam KCKT fasa terbalik, kepolaran fasa gerak sangat berperan dalam pemisahan. Kekuatan fasa gerak menunjukkan kepolarannya. Jika kepolaran berkurang, kekuatan fasa gerak juga berkurang. Fasa gerak yang bersifat polar akan berinteraksi dan larut dengan analit polar sehingga akan berpengaruh pada retensi analit. Apabila kepolaran fasa gerak berkurang, maka akan mengurangi retensi analit polar dalam fasa diam, sebaliknya jika kepolaran fasa gerak bertambah maka akan meningkatkan retensi analit dalam fasa diam. Biasanya, fasa gerak terdiri dari campuran air dengan pelarut organik, seperti asetonitril, metanol, dioksan, tetrahidrofuran, propanol. Penambahan pelarut organik dalam fasa gerak, dapat menurunkan kepolaran fasa gerak. Pengaturan fasa gerak dapat dilakukan melalui mode gradien elusi. Fasa gerak yang dialirkan secara gradien dapat diatur kepolarannya selama pemisahan berlangsung sehingga gradien dapat memperbaiki efisiensi pemisahan (Shrivastava and Gupta, 2012).

Berdasarkan hasil penelitian yang telah dilakukan, maka perlu dilakukan penelitian dalam penggunaan kolom monolith poli(LMA-co-EDMA) untuk meningkatkan efisiensi pemisahan alkilbenzena. Dalam penelitian ini digunakan kolom yang sama (batch dan ukuran yang sama, panjang $10 \mathrm{~cm}$ dan diameter dalam 1,02 inchi) dengan penelitian tersebut. Efisiensi pemisahan sampel alkilbenzena menggunakan kolom monolith poli(LMA-co-EDMA) menggunakan dilakukan dengan beberapa parameter, diantaranya temperatur dan kepolaran fasa gerak yang dialirkan secara gradien. Kromatogram pemisahan alkilbenzena yang dihasilkan selanjutnya dievaluasi parameter efisiensi pemisahan yang meliputi resolusi $(\mathrm{R})$, jumlah plat teoritis $(\mathrm{N})$, faktor retensi/kapasitas $(\mathrm{k})$, selektivitas $(\alpha)$, dan peak capacity (untuk gradien). Evaluasi secara lebih rinci parameter pemisahan diperlukan untuk mengetahui efisiensi dari penggunaan kolom poli-(LMA-coEDMA). 


\section{METODE PENELITIAN}

Bahan yang digunakan pada penelitian ini antara lain lauril metakrilat (LMA), etilen dimetakrilat (EDMA) 98\%, 1-propanol, 1,4-butandiol 99\%, 99\%, $\alpha-\alpha$ azoisobutyronitrile (AIBN), 3-methacryloxypropyl-trimethoxysilane (MAPS), natrium hidroksida $(\mathrm{NaOH})$, asam klorida $(\mathrm{HCl})$, aseton dan piridin berasal dari Sigma-Aldrich Corp. Larutan urasil 375 ppm (dari urasil 98\% (v/v)), larutan etil benzena 1\% (v/v) (dari etil benzena 99\% (v/v)), larutan propil benzena 1\% (v/v) (dari propil benzena 99\% (v/v)), larutan butil benzena 1\% (dari butil benzena 99\% (v/v)) dan larutan amil benzena 20\% (v/v) (dari amil benzena 98\% (v/v)) diperoleh dari Tokyo Chemical Industry (TCI). Asetonitril, toluen dan metanol didapatkan dari Merck. Etanol untuk KCKT diperoleh dari PT. Smart Lab Indonesia. Kolom silicosteel (diameter dalam 1,02 mm, diameter luar 1/16 inchi) serta akuademineral.

Alat yang digunakan pada penelitian ini meliputi seperangkat KCKT Shimadzu Prominence 20A (terdiri atas unit degasser DGU-20A, pengotrol CBM-20A, pompa LC-20 AD, oven CTO-20AC, detektor UV/Vis SPD-20AV, injektor Rheodyne 7125 dengan sample loop $2 \mu \mathrm{L}$ ), kolom monolith poli-(LMA-co-EDMA) $1 \mathrm{~mm}$ i.d x $100 \mathrm{~mm}$, internal union1/16" hingga 1"16" Supelco (Bellefonte, USA), tip dan mikropipet Eppendorf kapasitas $10 \mu \mathrm{L} ; 200 \mu \mathrm{L} ; 1000 \mu \mathrm{L}$ dan $5000 \mu \mathrm{L}$, oven, ultrasonikator, neraca analitik Adventer AR 2130, botol semprot dan peralatan gelas.

\section{Pembuatan Kolom Monolith Poli-(LMA-co-EDMA)}

Pembuatan kolom monolith poli-(LMA-co-EDMA) diawali dengan silanasi kolom silicosteel (diameter dalam 1,02 mm, diameter luar 1/16 inchi) yang digunakan sebagai kolom housing. Prosedur silanasi kolom mengacu pada prosedur yang telah dilakukan Shu et al. (2011). Kolom silicosteel dicuci menggunakan akuadem, diisi 0,2 M NaOH selama 2x30 menit, dicuci akuadem, diisi dengan 0,2 M HCl selama 2x30 menit, dicuci akuadem, lalu dicuci menggunakan aseton. Kolom kemudian diisi dengan 30\% MAPS dalam aseton dan piridin (MAPS:aseton:piridin = 30:65:5), kedua ujung kolom ditutup dan disimpan pada temperatur ruang selama $2 \times 12$ jam. Usai proses silanasi, kolom dicuci menggunakan aseton dan dipotong-potong sepanjang $10 \mathrm{~cm}$.

Kolom monolith poli-(LMA-co-EDMA) dibuat sesuai prosedur yang dilakukan oleh Sabarudin et al. (2012). Campuran polimer monolith ini terdiri dari monomer LMA $\% \mathrm{~T}=35 \%$, crosslinker EDMA $\% \mathrm{C}=10 \%$ dan campuran porogen 1-propanol:1,4butandiol $=7: 4$. Campuran polimer dihomogenkan, kemudian ditambahkan inisiator AIBN (1\% w/v). Campuran dihomogenkan kembali lalu dimasukkan ke dalam kolom silicosteel 
yang sudah tersilanasi dan ditutup kedua ujuang dari kolom silicosteel. Polimerisasi dilakukan di dalam oven pada $80{ }^{\circ} \mathrm{C}$ selama 12 jam. Kolom monolith poli-(LMA-coEDMA) yang telah dipolimerisasi dihubungkan ke pompa KCKT dan dicuci menggunakan metanol selama 1 jam dengan laju alir $0,02 \mathrm{~mL} / \mathrm{menit}$.

\section{Pembuatan Sampel Alkilbenzena}

Sampel alkilbenzena terdiri atas etil benzena $1 \%$, propil benzena $1 \%$, butil benzena $1 \%$, amil benzena $2 \%$ dan urasil 375 ppm. Masing-masing diambil sebanyak $1 \mathrm{~mL}$ menggunakan mikropipet, kemudian dimasukkan ke dalam botol sampel $5 \mathrm{~mL}$. Selanjutnya dihomogenkan menggunakan ultrasonikator selama 10 menit.

\section{Pemisahan Sampel Alkilbenzena Menggunakan Metode Isokratik}

Pemisahan sampel alkilbenzena dilakukan menggunakan KCKT dengan laju alir $0,05 \mathrm{~mL} / \mathrm{menit}$, fasa gerak yang digunakan asetonitril:air $(50: 50 \mathrm{w} / \mathrm{w})$, panjang gelombang UV-Vis $214 \mathrm{~nm}$ pada temperatur ruang. Pengaruh temperatur kolom dilakukan dengan menggunakan temperatur $30{ }^{\circ} \mathrm{C}, 40{ }^{\circ} \mathrm{C}$, dan $50{ }^{\circ} \mathrm{C}$ pada kondisi yang sama.

\section{Pemisahan Sampel Alkilbenzena Menggunakan Metode Gradien}

Pemisahan sampel alkilbenzena dilakukan menggunakan dua fasa gerak yang terdiri dari fasa gerak A adalah asetonitril:air (40:60 w/w) dan fasa gerak B adalah asetonitril:air (60:40 w/w), laju alir 0,10 mL/menit, panjang gelombang UV-Vis $214 \mathrm{~nm}$ pada temperatur ruang. Komposisi fasa gerak diatur dalam waktu 20 menit, 30 menit dan 40 menit.

\section{PEMBAHASAN}

\section{Pengaruh Temperatur Kolom}

Temperatur merupakan salah satu parameter yang berarti dalam teknik analisis kromatografi. Penggunaan temperatur kolom berpengaruh terhadap mekanisme pemisahan analit yang berkaitan dengan viskositas fasa gerak serta proses difusi dan transfer massa yang terjadi antara fasa diam dengan fasa gerak. Analisis pada studi ini dilakukan secara mode isokratik menggunakan eluen asetonitril:air $(50: 50 \mathrm{w} / \mathrm{w})$. Temperatur yang digunakan dibuat bervariasi, yaitu $27{ }^{\circ} \mathrm{C}, 30{ }^{\circ} \mathrm{C}, 40{ }^{\circ} \mathrm{C}$ dan $50{ }^{\circ} \mathrm{C}$. Pengaruh temperatur kolom KCKT ditunjukkan pada Gambar 2.

Kromatogram hasil pemisahan alkilbenzena menggunakan keempat temperatur kolom tersebut menunjukkan bahwa pemisahan alkilbenzena paling baik diberikan oleh temperatur ruang kolom yakni $27{ }^{\circ} \mathrm{C}$. Setiap puncak kromatogram terpisah dengan baik dibandingkan ketiga pengaruh temperatur kolom lainnya. Kromatogram pada Gambar 2 
menunjukkan bahwa seiring dengan kenaikan temperatur menyebabkan pemisahan alkilbenzena yang terjadi semakin cepat. Namun, puncak kromatogram pemisahan alkilbenzena yang dihasilkan tidak terpisah dengan baik. Hal ini disebabkan oleh berkurangnya viskositas dari fasa gerak asetonitril:air (50:50 w/w) dan tekanan balik pada kolom sehingga proses difusi dan transfer massa yang terjadi antara fasa gerak dengan fasa diam lebih mudah serta menurunnya kekuatan alkilbenzena untuk tertahan pada fasa diam ketika temperatur kolom dinaikkan.

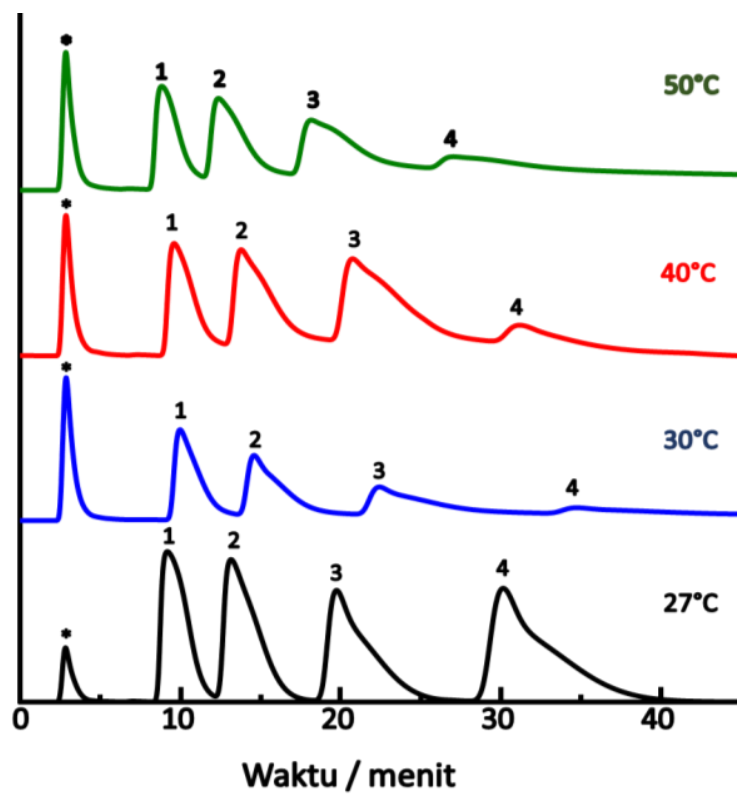

Gambar 2. Pemisahan alkilbenzena secara isokratik pada berbagai temperatur menggunakan kolom monolith poli-(LMA-co-EDMA). Fasa gerak: asetonitril-air (50:50 w/w); laju alir 0,05 mL/menit; volume injeksi: 0,2 $\mu \mathrm{L}$; deteksi UV: $214 \mathrm{~nm}$. Puncak: (*)

urasil, (1) etilbenzena, (2) propilbenzena, (3) butilbenzena dan (4) amilbenzena.

Efisiensi kolom direpresentasikan oleh jumlah plat teoritis merupakan ukuran dispersi pita analit yang melalui kolom kromatografi. Efisiensi pemisahan dipengaruhi oleh faktor kapasitas, selektivitas dan resolusi. Faktor kapasitas (k) merepresentasikan perbandingan distribusi jumlah analit pada fasa diam dan fasa gerak. Nilai faktor kapasitas yang baik berkisar 1-10, nilai tersebut memungkinkan pemisahan memiliki resolusi 1,5 yang merupakan resolusi yang baik. Resolusi bernilai 1,5 menunjukkan pemisahan memiliki efektivitas dan selektivitas yang baik dengan memberikan kemurnian analit mencapai $100 \%$. Selektivitas $(\alpha)$ merupakan kemampuan fasa diam untuk mengikat analit, nilai ini dipengaruhi oleh sifat fasa diam dan relatif konstan pada berbagai komposisi fasa gerak. Pemisahan dikatakan efisien apabila nilai selektivitas lebih dari 1,0. Resolusi (Rs) didefinisikan sebagai kemampuan sistem kromatografi untuk memisahkan komponen analit. Kemurnian komponen yang dipisahkan mencapai $100 \%$ pada resolusi bernilai lebih 
dari 1,5. Resolusi rendah (kurang dari 1,5) menyebabkan sebagian analit terelusi secara bersamaan, sehingga menghasilkan puncak kromatogram yang saling tumpang tindih (overlapping).

Efisiensi pemisahan dapat ditinjau dari parameter kromatografi meliputi faktor kapasitas (k), selektivitas ( $\alpha$ ) dan resolusi (Rs). Parameter kromatografi berdasarkan pengaruh temperatur kolom pada pemisahan alkilbenzena menggunakan kolom poli(LMA-co-EDMA) ditunjukkan oleh Tabel 1.

Tabel 1. Parameter kromatografi hasil pemisahan alkilbenzena berdasarkan pengaruh temperatur kolom.

\begin{tabular}{|c|c|c|c|c|c|}
\hline \multirow{2}{*}{ Temperatur } & \multirow{2}{*}{ Parameter } & \multicolumn{4}{|c|}{ Puncak } \\
\hline & & 1 & 2 & 3 & 4 \\
\hline \multirow{3}{*}{$27^{\circ} \mathrm{C}$} & $\mathrm{K}$ & 2,26 & 3,68 & 6,02 & 9,73 \\
\hline & A & 0,00 & 1,63 & 1,64 & 1,61 \\
\hline & Rs & 0,00 & 1,08 & 1,33 & 1,40 \\
\hline \multirow{3}{*}{$30{ }^{\circ} \mathrm{C}$} & $\mathrm{K}$ & 2,48 & 4,09 & 6,82 & 11,11 \\
\hline & $\mathrm{A}$ & 0,00 & 1,65 & 1,67 & 1,63 \\
\hline & Rs & 0,00 & 1,17 & 1,19 & 1,17 \\
\hline \multirow{3}{*}{$40{ }^{\circ} \mathrm{C}$} & $\mathrm{K}$ & 2,36 & 3,83 & 6,26 & 9,90 \\
\hline & A & 0,00 & 1,62 & 1,64 & 1,58 \\
\hline & Rs & 0,00 & 1,02 & 1,03 & 1,14 \\
\hline \multirow{3}{*}{$50{ }^{\circ} \mathbf{C}$} & $\mathrm{K}$ & 2,10 & 3,40 & 5,38 & 8,49 \\
\hline & $\mathrm{A}$ & 0,00 & 1,59 & 1,61 & 1,58 \\
\hline & Rs & 0,00 & 1,01 & 1,00 & 0,86 \\
\hline
\end{tabular}

Keterangan: Pemisahan alkilbenzena menggunakan kolom monolith poli-(LMA-co-EDMA) pada laju alir $0,05 \mathrm{~mL} /$ menit pada temperatur $27^{\circ} \mathrm{C}$. Faktor retensi (k), resolusi (Rs) dan selektivitas $(\alpha)$. Puncak: (1) etilbenzena, (2) propilbenzena, (3) butilbenzena dan (4) amilbenzena

Berdasarkan hasil yang telah diperoleh, peningkatan temperatur menyebabkan semakin pendek waktu analisis. Waktu analisis yang diperlukan pada temperatur kolom $27{ }^{\circ} \mathrm{C}, 30{ }^{\circ} \mathrm{C}, 40{ }^{\circ} \mathrm{C}$ dan $50{ }^{\circ} \mathrm{C}$ berturut-turut adalah sebagai berikut 30,15 menit; 34,75 menit; 31,18 menit dan 27,04 menit. Peningkatan temperatur kolom yang digunakan menyebabkan berkurangnya viskositas dari fasa gerak sehingga tekanan balik kolom menurun. Berikut pengaruh temperatur kolom pada tekanan balik 2,7 MPa pada $30{ }^{\circ} \mathrm{C}$; 2,3 $\mathrm{MPa}$ pada $40{ }^{\circ} \mathrm{C}$ dan 2,1 $\mathrm{MPa}$ pada $50{ }^{\circ} \mathrm{C}$. Oleh karena hal tersebut, proses difusi dan transfer massa antara fasa gerak dengan fasa diam lebih mudah terjadi dan waktu pemisahan alkilbenzena semakin cepat. Selain itu, kekuatan alkilbenzena untuk tertahan pada fasa diam semakin berkurang karena proses difusi analit semakin mudah seiring dengan meningkatnya temperatur kolom. Peristiwa ini diperlihatkan dengan menurunnya nilai dari faktor kapasitas dan selektivitas. 
Pemisahan yang paling efisien diperoleh pada pemisahan alkilbenzena menggunakan kolom monolith poli-(LMA-co-EDMA) menggunakan fasa gerak asetonitril:air $(50: 50 \mathrm{w} / \mathrm{w})$ secara isokratik diperoleh pada temperatur $27{ }^{\circ} \mathrm{C}$. Hal ini ditunjukkan oleh menurunnya jumlah plat teoritis $(\mathrm{N})$ yang diperlihatkan pada Gambar 3. Jumlah plat teoritis digunakan untuk merepresentasikan efisiensi kolom. Efisiensi kolom merupakan ukuran dispersi pita analit yang melalui kolom. Jumlah plat teoritis yang menghasilkan pemisahan yang baik miniman berjumlah 2000 plat (Shrivastava and Gupta, 2012).

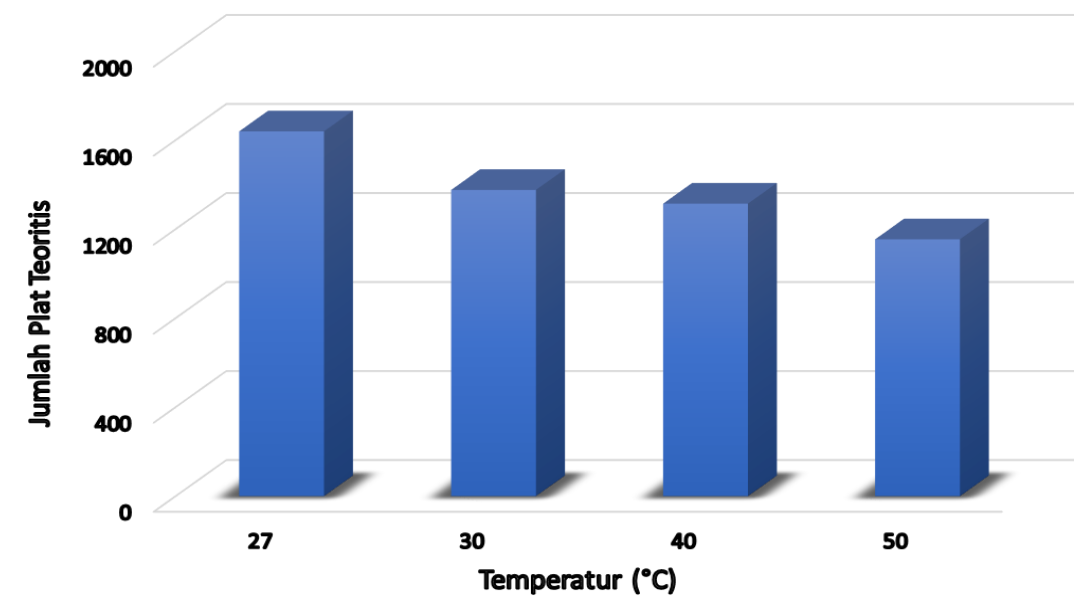

Gambar 3. Data hubungan antara jumlah plat teoritis terhadap variasi temperatur.

\section{Perbandingan Efisiensi Pemisahan Secara Isokratik dan Gradien}

Pemisahan alkilbenzena secara gradien pada penelitian ini menggunakan dua fasa gerak yakni asetonitril: air (40:60 (w/w)) 100-0\% dan asetonitril:air (60:40 (w/w)) 0-100\%. Penggunaan komposisi fasa gerak yang berbeda dipertimbangkan terhadap mekanisme pemisahan analit yang dipengaruhi oleh perbedaan tingkat kepolaran. Penambahan komposisi dari asetonitril diharapkan memberikan hasil pemisahan yang lebih baik dibandingkan mode isokratik. Untuk mengetahui pengaruh mode elusi yang digunakan, kromatogram pemisahan alkilbenzena mode gradien yang dihasilkan kemudian dibandingkan dengan kromatogram pemisahan alkilbenzena mode isoratik. Kromatogram pemisahan alkilbenzena secara gradien maupun isokratik menggunakan kolom monolith poli-(LMA-co-EDMA) ditunjukkan oleh Gambar 4.

Kromatogram hasil pemisahan alkilbenzena yang diperoleh, menunjukkan apabila penggunaan mode elusi isokratik memberikan hasil yang kurang tajam dan terdapat pelebaran puncak. Salah satu usahan untu mengatasi hal tersebut adalah dengan melakukan mode elusi gradien yang melibatkan perubahan komposisi fasa gerak selama sistem KCKT berjalan. Pemisahan alkilbenzena secara mode elusi gradien menghasilkan puncak 
kromatogram yang lebih tajam dan mengurangi pelebaran puncak. Dengan demikian, penggunaan mode elusi gradien terbukti mampu memperbaiki efisiensi pemisahan alkilbenzena.

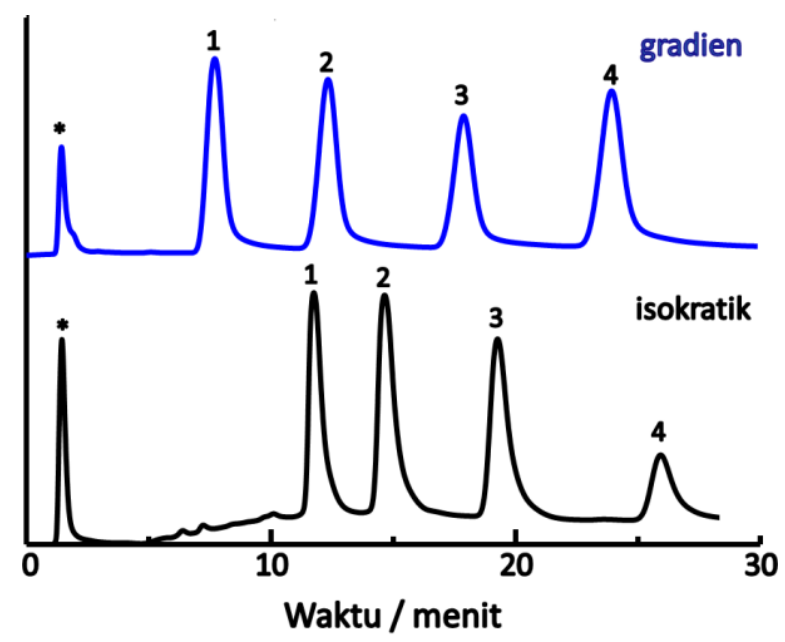

Gambar 4. Pemisahan alkilbenzena secara isokratik dan gradien elusi menggunakan kolom monolith poli-(LMA-co-EDMA). Fasa gerak elusi isokratik: asetonitril-air (50:50 $\mathrm{w} / \mathrm{w})$ sedangkan fasa gerak elusi gradien: fasa gerak A: asetonitril-air (40:60 w/w); fasa gerak B: asetonitril-air (60:40 w/w); laju alir 0,1 mL/menit; volume injeksi: 0,2 $\mu \mathrm{L}$; deteksi UV: 214 nm. Puncak: (*) urasil, (1) etilbenzena, (2) propilbenzena, (3) butilbenzena dan (4) amilbenzena.

Tabel 2. Parameter kromatografi hasil pemisahan alkilbenzena berdasarkan pengaruh mode elusi yang digunakan

\begin{tabular}{|c|c|c|c|c|c|c|c|}
\hline Mode & Puncak & $\mathbf{t}_{\mathbf{r}}$ & W & $\mathbf{K}$ & $\alpha$ & $\mathbf{N}$ & Rs \\
\hline \multirow[t]{6}{*}{ Isokratik } & 1 & 11,74 & 1,16 & 7,1 & & 16388,5 & \\
\hline & 2 & 14,64 & 1,4 & 9,1 & 1,28 & 17496,3 & 2,27 \\
\hline & 3 & 19,25 & 1,63 & 12,28 & 1,35 & 22315,5 & 3,04 \\
\hline & 4 & 25,92 & 1,99 & 16,88 & 1,37 & 27144,6 & 3,69 \\
\hline & \multicolumn{4}{|c|}{ Rata-rata } & \multicolumn{3}{|c|}{20836,2} \\
\hline & Puncak & tr & $\mathbf{W}$ & $\mathbf{k}^{*}$ & $\alpha^{*}$ & Pc & Rs \\
\hline \multirow[t]{4}{*}{ Gradien } & 1 & 7,70 & 1,3 & 9,73 & & & \\
\hline & 2 & 12,32 & 1,5 & 9,12 & 1,07 & 224 & 3,34 \\
\hline & 3 & 17,87 & 1,6 & 8,65 & 1,05 & & 3,62 \\
\hline & 4 & 23,91 & 1,8 & 8,22 & 1,05 & & 3,52 \\
\hline
\end{tabular}

Keterangan: Pemisahan alkilbenzena menggunakan kolom monolith poli-(LMA-co-EDMA) pada laju alir 0,1 $\mathrm{mL} /$ menit dan temperatur $27^{\circ} \mathrm{C}$. Waktu retensi $\left(\mathrm{t}_{\mathrm{r}}\right)$, lebar puncak $(\mathrm{w})$, faktor retensi $(\mathrm{k})$, selektivitas $(\alpha)$, jumlah plat teoritis $(\mathrm{N})$, resolusi (Rs) dan peak capacity $(\mathrm{Pc})$. Puncak: (1) etilbenzena, (2) propilbenzena, (3) butilbenzena dan (4) amilbenzena.

Berdasarkan kromatogram diatas, data hasil pemisahan alkilbenzena secara gradien dan isokratik meliputi waktu retensi (tr), lebar puncak (w), faktor kapasitas (k), jumlah plat teoritis (N) dan resolusi (Rs) dirangkum pada Tabel 2. Data faktor retensi dari kedua mode elusi tersebut menunjukkan jika nilai faktor retensi mode elusi gradien mengalami penurunan jika dibandingkan dengan faktor retensi mode isokratik. Hasil tersebut 
disebabkan oleh semakin besar konsentrasi asetonitril, menyebabkan waktu pemisahan alkilbenzena semakin cepat. Hal ini berkaitan dengan perbedaan polaritas, senyawa alkilbenzena memiliki kepolaran yang rendah (P'benzena $=3$ ) sedangkan fasa gerak asetonitril-air (50:50 w/w) memiliki polaritas yang lebih tinggi (P'asetonitril-air (50:50 $\mathrm{w} / \mathrm{w})=7,432)$ yang masih lebih rendah dibandingkan dengan polaritas air $\left(\mathrm{P}^{\prime}\right.$ air $\left.=9\right)$ (Ramis-Ramos and eGarcia, 2013). Semakin tinggi polaritas fasa gerak akan mengakibatkan alkilbenzena lebih banyak terdistribusi pada fasa diam dengan penggunaan kolom fasa terbalik, sehingga waktu pemisahan berjalan lebih lambat. Hal tersebut disebabkan oleh kecenderungan alkilbenzena untuk tertahan pada fasa diam seiring dengan penambahan asetonitril yang berpengaruh terhadap nilai faktor retensi.

\section{Pengaruh Perubahan Waktu Gradien}

Pemisahan alkilbenzena dengan mode gradien dalam penelitian ini menggunakan dua fasa gerak, fasa gerak A terdiri dari asetonitril-air $(40: 60 \mathrm{w} / \mathrm{w})$ dan fasa gerak B terdiri atas asetonitril-air $(60: 40 \mathrm{w} / \mathrm{w})$ dengan pengaturan fasa gerak B: 0-100\%. Perubahan komposisi fasa gerak yang digunakan berpengaruh terhadap kepolaran dari fasa gerak seiring dengan peningkatan komposisi asetonitril pada fasa gerak B. Akibatnya, terjadi perubahan parameter pemisahan seperti faktor retensi dan peak capacity. Pada penelitian ini, waktu gradien yang digunakan yakni 20 menit, 30 menit dan 40 menit. Hasil pemisahan alkilbenzena dengan pengaruh perubahan waktu gradien ditunjukkan pada Gambar 5.

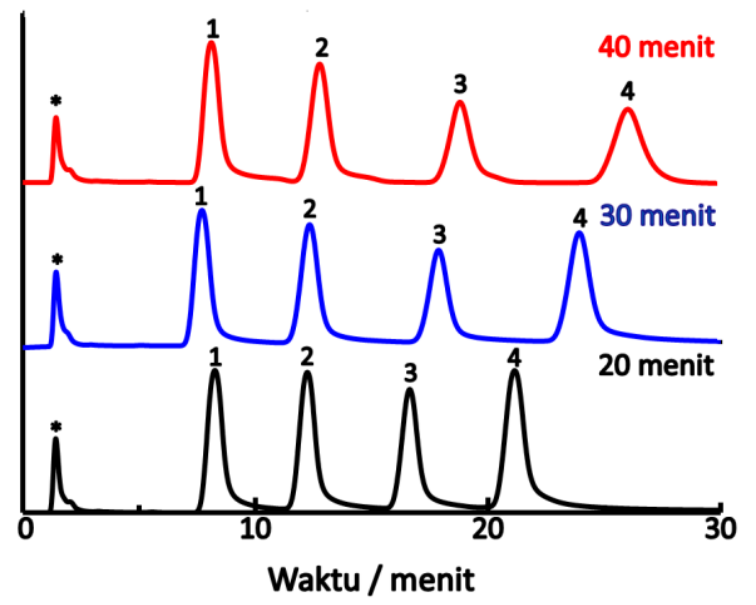

Gambar 5. Pemisahan alkilbenzena secara gradien elusi menggunakan kolom monolith poli-(LMA-co-EDMA). Fasa gerak A: asetonitril-air (40:60 w/w); fasa gerak B: asetonitrilair $(60: 40 \mathrm{w} / \mathrm{w})$; laju alir 0,1 mL/menit; volume injeksi: 0,2 $\mu \mathrm{L}$; deteksi UV: $214 \mathrm{~nm}$.

Puncak: (*) urasil, (1) etilbenzena, (2) propilbenzena, (3) butilbenzena dan (4) amilbenzena. 
Kromatogram seperti pada Gambar 5 menunjukkan waktu gradien yang digunakan berpengaruh terhadap pemisahan alkilbenzena. Semakin bertambah waktu gradien yang digunakan, semakin bertambah faktor retensi dari masing-masing puncak alkilbenzena. Hal ini berkaitan dengan polaritas fasa gerak, semakin sedikit komposisi fasa gerak yang mengandung asetonitril menyebabkan kepolaran fasa gerak bertambah. Akibatnya, alkilbenzena lebih banyak terdistribusi pada fasa diam sehingga alkilbenzena tertahan dalam kolom lebih lama. Namun, ketika komposisi asetonitril dalam fasa gerak semakin banyak maka alkilbenzena lebih terdistribusi pada fasa gerak sehingga keluar dari kolom lebih cepat.

Penambahan waktu gradien pada pemisahan alkilbenzena menyebabkan perubahan dari nilai peak capacity yang berpengaruh pada efisiensi pemisahan. Semakin lama waktu gradien yang digunakan, semakin banyak jumlah peak capacity yang dihasilkan. Melalui perhitungan nilai peak capacity yang didapatkan, diketahui bahwa nilai peak capacity berbanding lurus dengan waktu gradien. Namun demikian, pengaruh waktu gradien tidak berpengaruh terhadap selektivitas pemisahan. Semakin lama penambahan waktu gradien, selektivitas pemisahan cenderung tidak berubah secara signifikan. Hal tersebut dikarekan perbandingan faktor retensi antara puncak satu dengan puncak yang lain tidak berubah. Selektivitas pemisahan alkilbenzena pengaruh waktu gradien disajikan pada Tabel 3.

Tabel 3. Selektivitas pemisahan alkilbenzena secara gradien

\begin{tabular}{cccccccc}
\hline tg & Puncak & $\mathbf{T r}$ & $\mathbf{w}$ & $\mathbf{k}^{*}$ & $\boldsymbol{\alpha}^{*}$ & $\mathbf{P c}$ & $\mathbf{R s}$ \\
\hline \multirow{3}{*}{ 20 menit } & 1 & 8,25 & 1,25 & 6,49 & & & \\
& 2 & 12,23 & 1,3 & 6,08 & 1,07 & 165 & 3,11 \\
& 3 & 16,63 & 1,35 & 5,77 & 1,05 & & 3,24 \\
\multirow{3}{*}{30 menit } & 4 & 21,14 & 1,5 & 5,48 & 1,05 & & 2,99 \\
& 1 & 7,70 & 1,3 & 9,73 & & & \\
& 2 & 12,32 & 1,5 & 9,12 & 1,07 & 224 & 3,34 \\
& 3 & 17,87 & 1,6 & 8,65 & 1,05 & & 3,62 \\
\multirow{3}{*}{ 40 menit } & 4 & 23,91 & 1,8 & 8,22 & 1,05 & & 3,52 \\
& 1 & 8,10 & 1,3 & 12,97 & & & \\
& 3 & 12,76 & 1,5 & 12,17 & 1,07 & 258 & 3,20 \\
& 4 & 18,79 & 1,8 & 11,53 & 1,06 & & 3,55 \\
& 2 & 26,0 & 2,5 & 10,96 & 1,05 & & 3,35 \\
\hline
\end{tabular}

Keterangan: Pemisahan alkilbenzena menggunakan kolom monolith poli-(LMA-co-EDMA) pada laju alir 0,1 $\mathrm{mL} /$ menit dan temperatur $27^{\circ} \mathrm{C}$. Waktu gradien $\left(\mathrm{t}_{\mathrm{g}}\right)$, retensi $\left(\mathrm{t}_{\mathrm{r}}\right)$, lebar puncak $(\mathrm{w})$, faktor retensi $\left(\mathrm{k}^{*}\right)$, selektivitas $\left(\alpha^{*}\right)$, resolusi $(\mathrm{Rs})$ dan peak capacity $(\mathrm{Pc})$. Puncak: (1) etilbenzena, (2) propilbenzena, (3) butilbenzena dan (4) amilbenzena. 


\section{KESIMPULAN}

Senyawa alkilbenzena dapat dipisahkan menggunakan kolom monolith berbasis polimer organik. Temperatur kolom dan mode elusi yang digunakan berpengaruh terhadap pemisahan alkilbenzena. Temperatur optimum kolom pada pemisahan alkilbenzena diperoleh pada temperatur ruang $\left(27^{\circ} \mathrm{C}\right)$. Penggunaan mode elusi gradien pada pemisahan alkilbenzena dengan menggunakan asetonitril:air (40:60 w/w) sebagai fasa gerak A dan asetonitril:air (60:40 w/w) sebagai fasa gerak B mampu meningkatkan efisiensi pemisahan senyawa alkilbenzena. Perubahan waktu gradien pada pemisahan alkilbenzena berpengaruh terhadap komposisi fasa gerak, serta nilai dari peak capacity dan faktor retensi yang dihasilkan.

\section{DAFTAR PUSTAKA}

Dolan, J.W., 2002. Temperature selectivity in reversed-phase high performance liquid chromatography. Journal of Chromatography A 965, 195-205.

Giddings, J.C., 1965. Dynamics of Chromatography Part I. Principles and Theory. Marcel Dekker. New York. 283.

Gritti, F., and Guiochon, G., 2013. The van Deemter equation: Assumptions, limits, and adjustment to modern high performance liquid chromatography. Journal of Chromatography A 1302, 1-13.

Hao, Z., Xiao, B., and Weng, N., 2008. Impact of column suhu and mobile phase components on selectivity of hydrophilic interaction chromatography (HILIC). Journal of Separation Science 31, 1449-64.

Krenkova, J., Gargano, A., Lacher, A., Schneiderheinze, J.M., and Svec, F., 2009. High binding capacity surface grafted monolithic column or cation exchange chromatography of proteins and peptides. Journal of Chromatography A, 1216, 6824-6830.

Mangelings, D., and Heyden, Y.V., 2010. Application of monolithic chromatography in pharmaceutical analysis, in: Wang, P.W. (Ed.), Monolithic Chromatography and Its Modern Applications. ILM Publication. USA. pp. 177-202.

Moyna, A., 2012. The fabrication and modification of capillary polymer monoliths for the separation of small ions. Dublin City University.

Nema, T., Chan, E.C.Y. and Ho, P.C., 2014. Applications of monolithic for sample preparation. Journal of Pharmaceutical and Biomedical Analysis 87, 130-141.

Ramis-Ramos, G., and eGarcia-Alvarez-Coque, M.C., 2013. Solvent Selection in Liquid Chromatography, in: Fanali, S., Haddad, P.R., Poole, C., Schoenmakers, P.J., et al. (Eds.). Liquid Chromathography: Fundamentals and Instrumentation. Elsevier, Amsterdam. Boston. pp. 225-245.

Sabarudin, A., Huang, J., Shu, S., Sakagawa, S., and Umemura, T., 2012. Preparation of methacrylate-based anion-exchange monolithic microbore column for 
chromatographic separation of DNA fragments and oligonucleotides. Analytica Chimica Acta 736, 108-114.

Shrivastava, A., and Gupta, V.B., 2012. HPLC: Isocratic or Gradient Elution and Assessment of Linearity In Analytical Methods. Journal of Advanced Scientific Research 3.

Shu, S., Kobayashi, H., Kojima, N., Sabarudin, A., and Umemura, T., 2011. Preparation and characterization of lauryl methacrylate-based monolithic microbore column for reversed-phase liquid chromatography. Journal of Chromatography A 1218, 52285234.

Shu, S., Kobayashi, H., Okubo, M., Sabarudin, A., Butsugan, M., and Umemura T., 2012. Chemical anchoring of lauryl methacrylate-based reversed phase monolith to $1 / 16^{\prime \prime}$ o.d. polyetheretherketone tubing. Journal of Chromatography A 1242, 59-66.

Synder, L.R., and Kirkland, J.J., 1979. Introduction to Modern Liquid Chromatography. 2nd ed. John Wiley \& Sons, Inc. New York.

Tasfiyati, A.N., Iftitah, E.D., Sakti, S.P., and Sabarudin, A., 2016. Evaluation of Glycidyl Methacrylate-Based Monolith Functionalized with Weak Anion Exchange Moiety Inside 0.5 Mm I.d. Column for Liquid Chromatographic Separation of Dna. Analytical Chemistry Research 7, 9-16.

Unger, K.K., Lamotte, S., and Machtejevas, E., 2013. Column technology in Liquid Chromatography, in: Fanali, S., Haddad, P.R., Lloyd, D., Poole, C.F., et al. (Eds.), Liquid Chromatography. Fundamentals and Instrumentation/[Edited by] Salvatore Fanali, Paul R. Haddad, Colin F. Poole, Peter Schoenmakers, David Lloyd, Elsevier, Amsterdam, 42-67. 